\title{
Technology in Feeding Management to Increase Ruminant Productivity
}

\author{
Budi Haryanto \\ Indonesian Research Institute for Animal Production, PO Box 221, Bogor 16002, West Java \\ budiharyanto_51@yahoo.com
}

(Diterima 16 Januari 2015 - Direvisi 21 Agustus 2015 - Disetujui 23 Oktober 2015)

\begin{abstract}
Traditional feeding management in ruminants is defined by allowing the animal to find their own feed, consisted of raw materials of grasses and leguminous foliages as much as possible (ad libitum) to get a high productivity; however, it needs longer period of time to reach maximum level of production. An advanced feeding management of ruminant is defined as: (1) Processing feed ingredients to improve the nutritive value; (2) Supplementing the animal with substances into the dietary formula to manipulate the rumen ecosystem either by reducing the protozoa population, increasing the concentration of certain nutrients, changing the rumen characteristics; and (3) Changing the site of digestion of the nutrients to increase the absorption and feed utilization. Many research works have been carried out to evaluate the effects of process technology on the efficiency of feed utilization. Improving feeding management will increase livestock production.
\end{abstract}

Key words: Feeding management, supplement, rumen ecosystem, productivity

\section{ABSTRAK}

Teknologi dalam Pemberian Pakan untuk Meningkatkan Produktivitas Ruminansia

Manajemen pemberian pakan ternak ruminansia secara tradisional adalah dengan cara menggembalakan ternak untuk memperoleh hijauan pakan berupa rumput dan leguminosa secara ad libitum untuk menghasilkan produksi yang optimal. Cara pemberian pakan tersebut memerlukan waktu lama untuk menghasilkan produksi ternak yang tinggi. Pakan berteknologi maju melalui: (1) Pengolahan bahan pakan untuk meningkatkan kualitas nutrisi bahan tersebut; (2) Pemberian pakan suplemen untuk mempengaruhi kinerja ekosistem rumen dengan menekan populasi protozoa, meningkatkan konsentrasi nutrien tertentu, merubah karakteristik rumen; dan (3) Proteksi bahan pakan dari kecernaan di rumen untuk meningkatkan penyerapan dan pemanfaatan pakan. Telah banyak dilakukan penelitian untuk menguji pengaruh pengolahan bahan pakan terhadap efisiensi pemanfaatan bahan pakan tersebut. Perbaikan manajemen pemberian pakan dapat meningkatkan produktivitas ternak.

Kata kunci: Manajemen pemberian pakan, suplemen, ekosistem rumen, produktivitas

\section{INTRODUCTION}

Ruminant animals, in their natural habitat, basically eat fibrous feeds as nutrient resources for their maintenance and production requirements. Natural grasses and leguminous foliages are the primary resources of fibrous feeds. However, ruminant animals will not be able to digest the fibrous nutrients from those grasses and leguminous foliages without the help of microbial enzymatic activities in the digestive tract. The interrelationship between ruminants and the microbial species inhabiting in the rumen plays basic knowledge of the current feeds and feeding management to maximize the efficiency of fibrous feed utilization. Host animals can help the microbial enzymatic activity by eating processes series to increase the surface area of feed particle by reducing the sizes, such as by chewing, mastication, regurgitating, mixing the digested feeds and transporting along the digestive tract. The microbes help hydrolyzing the feed particle by providing enzymes necessary for the digestion of respective nutrients, i.e., protein, lipids and fibrous components. The highly specificity of the enzymes to each chemical reaction makes the microbes to exert many kind of enzymes suited the needs of nutrient components, either for degrading down or building up processes. Therefore, hundreds of microbial species could be found in the rumen ecosystem, with their respective specific interaction and synergetic activities.

Ruminants require all nutrients for the normal productive physiological metabolism. In addition to the major nutrients such as protein, carbohydrates, and lipids, ruminants also need minerals, vitamins and other essential nutrients. In general, the animal requires feed to fulfill the needs for energy, which may come from carbohydrate, lipids and protein, whereas the products of animals may also contain the necessary components such as protein, fat, vitamins and minerals in a variable concentration. Ruminants may use protein from feeds and/or protein from microbial mass cells for their tissue metabolisms. Therefore, increasing the 
microbial protein synthesis de novo is an alternative strategy to satisfy the protein needs of the animal. The efficiency of microbial protein synthesis depends on the availability of ammonia and energy in the rumen ecosystem, therefore it can be enforced by manipulating the rumen ecosystem. The greatest challenge of tomorrow's nutritionist is to provide local feed energy resources and to enhance nutrient utilization, allowing a high yield of animal product without reliance on imported cereal grains and oilseed meals (Hegarty 2012).

The objective of the present paper is to describe the advanced feeding system in comparison to the common system carried out by farmers with natural raw feedstuffs. Technology for feedstuffs treatments and the appropriate use of the feedstuffs in the total mixed ration is expected to improve the ruminant production.

\section{NATURAL VERSUS HOUSED FEEDING OF LIVESTOCK}

Natural feeding versus housed feeding is distinguished by the feedstuffs being given to the animal. In natural feeding, the animal is fed with raw feedstuffs without any processing technique applied and the animal is allowed to choose them freely such as those in a grazing system or in a limited cut and carry cafeteria feeding system. In the housed feeding system, the feedstuffs are either being processed (chemical, physical or biological) before it is offered to the animal, and may be mixed in a formulated ration, or supplemented with any substance which is not taken by the animal under natural feeding condition. Therefore, there are two possible systems, which are known as extensive and intensive feeding systems.

\section{Extensive system}

In extensive feeding system, the animals are allowed to find their own needs for energy and other nutrients by scavenging grasses or green leaves within an open grazing land, pasture or under estate crop in an integrated crop-livestock system without intervention from farmers, except fencing from paddock to paddock. The productivity of animals is highly depended on the quality and quantity of grasses and green leaves available in the area.

Extensive feeding practice in grazing management actually is the most efficient feeding systems since there is not significant cost required. However, the production of the livestock is generally low and takes a longer time. Under grazing system, the nutrient availability may be inadequate to fulfill the animal's requirement for higher production due to the lack of some essential nutrients. The nutrient contents of the vegetation in a grazing area depend on the soil fertility and also on the vegetation characteristics. Supplementation with mineral or salts may be required for animals in grazing system.

\section{Intensive system}

Contrary to the extensive feeding system, in intensive feeding system the animals are fed with grasses or green leaves, concentrate and other supplements to fulfill the daily energy and nutrient requirements. The feeds may be formulated by farmers using several feed ingredients in a total mixed ration, includes supplements for minerals and vitamins. It is possible to modify the dietary nutritive value by formulating rations using several locally available feedstuffs, which may provide adequate nutrients at a level required for maximal livestock production. The animals are not allowed to find the feed voluntarily but they are forced to receive the offered feeds as a total mixed ration (TMR). In intensive feeding system, the animal depends on the animal raiser (farmer) for their daily needs of feed because they cannot find the feed by themselves. In these circumstances, the farmer should offer the appropriate feed, either in the form of grass forages, leguminous foliages or concentrate feed.

\section{BASIC CONCEPT OF NUTRITION IN RUMINANTS}

Basic concept behind the practical feeding management is related to the process of digestion, fermentation and metabolism that should be interconnected each other so that, there will be a continuous flow of nutrients from mouth to animal products. Feed consumed by the animal will be chewed in the mouth, masticated, mixed with digestive enzymes, transferred to the rumen for further enzymatic digestion and fermentation with the help of microbes in the rumen; before further digestion, the bolus of digesta will be regurgitated and re-masticated to reduce the particle size even further to make it easier for the enzymatic digestion. After ruminal fermentation then the feed particles will be transported to the lower digestive tract for further hydrolysis and absorption through the rumen or intestinal wall following the circulation of the blood to the liver. Nutrients metabolism may take place in the liver or in the tissue level before being deposited as animal products in the form of meat or milk, protein or fat depending on the nutrient balance condition.

Providing nutrients for optimum animal production, i.e., at a level close to that of the genetic potential of the animal can be carried out by fulfilling all the requirements for metabolic needs. For instance, 
if the animal can produce daily live weight gain at a rate of $1 \mathrm{~kg}$ then all the nutrients deposited in this gain should be satisfied from the metabolized nutrients. Therefore, considering the quantity of nutrient intake, digestion, fermentation, absorption, metabolism and deposition, the feed can be formulated, so that the animal requirement is satisfied. Even though interaction among those factors is important, those factors can be fractionated from one to another for further elucidation.

Nutrient intake is affected by the feedstuff's palatability and carrying capacity of the digestive tract, especially the capacity of rumen space to keep the feed for a certain period of time before being transferred to the subsequent section of the tract.

Digestion is affected by the structural characteristics of the feedstuffs, availability of enzymes and the microbial enzyme variability and suitability to the feed components. The interaction between feedstuffs and the enzymes play an important role in the digestion process. The synergistic effects of the available microbes in producing enzymes necessary for the process of digestion is also an important factor.

Fermentation of feed organic matter is carried out by microbial enzymes with ultimate production of volatile fatty acids, $\mathrm{CO}_{2}, \mathrm{H}_{2}$, methane and microbial mass. Ruminants rely on volatile fatty acids for the energy requirement. The microbial mass is used by the animals as source of protein. The higher content of lignocellulosic material in the feed generally resulted in higher production of methane, suggesting that more energy from feed is not utilized by the animal. Approximately $15 \%$ of the intake of dietary gross energy is loss as methane.

Absorption is affected by the healthiness of the digestive tract where the site of absorption occurs. Most parts of the microbial fermentative results are absorbed in the rumen or abomasum, and some parts will be absorbed along the intestinal tract, especially in the duodenum. The caecum is also an important site of nutrients absorption, especially for the hind gut fermentation.

Metabolism of nutrients which mostly take place in the liver and other tissues determine the ultimate fate of the nutrient intake, whether they will be deposited as protein or fat, either in meat or milk. The metabolic processes are not that simple due to thousands of enzyme catalyzed chemical reactions involve in the whole processes. It is only for simplicity that metabolism is associated with two processes, i.e., anabolism and catabolism depending on the nutrient balances.

The main objective of keeping livestock is to provide animal's products for human consumption. Meat, milk and other derivative products of them are the major target of more efficient livestock management. Since most production cost of livestock is devoted for feed, therefore it is understandable that attention should be directed to how to make efficient feeding expenses.

\section{Role of microbes in feed degradation}

Ruminants have specific digestion characteristics due to the activity of microbes in the rumen. The microbes can be classified as bacteria, protozoa and fungi. These microbes have interaction and synergism among each other in utilizing of organic material from feeds. The interaction may be antagonistic, symbiotic, or synergistic. The ecological system of the rumen changes dynamically from time to time depending on the process of organic matter digestion and fermentation. The factors affecting the dynamic ecosystem of rumen includes $\mathrm{pH}$, osmotic pressure, ammonia concentration, $\mathrm{CO}_{2}$ and $\mathrm{H}_{2}$ concentration, nutrients availability, volatile fatty acids concentration and may be antibiotic. The enzymatic potency of the rumen microbes is the key factor in dietary nutrient utilization in ruminants. Therefore, the benefit of rumen microbial activity is that the animal will have adequate available nutrients by utilizing the microbial fermentation products as well as the microbial mass itself. Nutrient dynamics, however, impact not only on pathway inputs but also the turnover and output of the whole ecosystem. Knowledge of the optimal balance of metabolic processes and the corresponding microbial taxis required to provide a stable, balanced ecosystem would enable a more holistic understanding of the rumen (Edwards et al. 2008).

\section{MANIPULATING EFFICIENCY OF FEED UTILIZATION}

Changes in rumen ecosystem can be done by modulated the activity of rumen microbes in producing the enzymes required for the fermentation of feed organic matter (Haryanto 2014). These dynamic changes of rumen ecosystem open the possibility to manipulate the dietary nutrient utilization. Affecting the hydroxy ion concentration $(\mathrm{pH})$ may change population of the rumen microbes, especially the protozoa and bacteria, by which the synergistic process of the available microbes will drive the $\mathrm{pH}$ back to the normal condition; meanwhile the fermentation of feed organic matter resulted in the formation of acids which will reduce the $\mathrm{pH}$, then the population of protozoa will increase and as predator of bacteria, therefore the population of bacteria will be lowering down and followed by increasing back the $\mathrm{pH}$ to normal. This process occurs continuously resulting in the dynamic system of rumen fermentation activities. Similarly, the 
concentration of ammonia increased the microbial protein synthesis then followed by lowering down the concentration of ammonia in the rumen; the urea cycle in the ruminants help maintaining ammonia concentration in the rumen by gradient diffusion between blood circulatory system and the rumen ecosystem.

\section{Soluble fraction of forage}

Changing the degradability of nutrients in the rumen may change the site of digestion, which is expected to be more efficiently utilized by the animal; changing the osmotic pressure, such as saponification may change the microbial population, hence the fermentation process will also change. Supplementation of polyether antibiotics may modify the microbial population and may change the fermentation activity. Supplementation of soluble fraction of forages may also affect the efficiency of fermentation because soluble fraction of forages are readily digested and therefore accelerate the subsequent processes of digestion. The fact that absorption of nutrients mostly occur in the lower digestive tract, therefore changing the site of digestion may also affect the efficiency of feed utilization. This is true especially for the protein, fat or mineral fraction in which the digestion may be moved to the lower digestive tract by protecting the protein, fat of mineral entity so that they will not be digested in the rumen but still hydrolysable in the lower tract.

Modifying ruminal microbial metabolism of fatty acid in rumen through animal diet formulation is an effective way to enhance these functional fatty acids in ruminant-derived food products. However, it requires an understanding of the interrelationship between supply of lipid through the diet and rumen fermentation. Lipid in ruminant diets undergo extensive hydrolysis and biohydrogenation in the rumen. Apparent transfer efficiency of eicosapentaenoic acid and docosahexaenoic acid from feed to milk was very low (1.9 to $3.3 \%$ ), which was, to a large extent, related to their extensive biohydrogenation in the rumen. Therefore, feeding a rumen-protected supplement containing eicosapentaenoic acid and docosahexaenoic acid, could be used to bypass the rumen (Or-Rashid et al. 2009).

\section{Energy to protein ratio in rumen metabolism}

The balance contents of the dietary energy and protein with further consideration of undegradability in the rumen may increase the efficiency of animal production. Synchronized availability of ammonia and energy in the rumen increased the microbial protein synthesis by which will increase the animal productivity in terms of meat or milk. The efficiency of microbial protein synthesis varied depending on the balance between ammonia and energy availability in rumen and it averages $30 \mathrm{~g}$ microbial $\mathrm{N}$ per $\mathrm{kg}$ fermented organic matter. There was a linear increase in final body weight and average daily gain (ADG) and a trend for a linear increase in dry matter intake (DMI) associated with increasing intake of degradable protein (DIP) concentration within the $5.1 \%$ intake of undegradable protein (UIP) treatments. Feed efficiency and net energy (NE) recovered from the diet were not influenced by dietary DIP concentration (Wagner et al. 2010). Certain rumen microorganisms were sensitive to a shortage of nitrogen; rumen concentrations of ammonia were $49 \%$ lower when the low-protein (LP) diets were consumed as were total bacteria $(-13 \%)$, anaerobic fungi $(-28 \%)$, methanogens $(-27 \%)$, protozoa $(-19 \%)$, cellulolytic bacteria and microbial diversity compared with when the high-protein (HP) diets were consumed. As a result, the digestibility of the LP diets was less than that of the HP diets. These findings demonstrated that the rumen microbial ecosystem is directly linked to the rumen fermentation pattern and, to some extent, to the efficiency of diet utilization by dairy cattle (Belanche et al. 2012).

\section{Digestible versus less digestible protein}

Positive effects of feeding more of the rumen undegradable protein (RUP) increased feed efficiency and fat corrected milk (FCM) plus $1.8 \mathrm{~kg} / \mathrm{d}$ greater FCM and $0.08 \mathrm{~kg} / \mathrm{d}$ greater fat, but milk protein content was lower and milk urea $\mathrm{N}$ and urinary urea excretion were elevated. Supplementation with rumen-protected methionine (RPM) increased DM intake $0.7 \mathrm{~kg} / \mathrm{d}$ and FCM and fat yield by 1.4 and $0.06 \mathrm{~kg} / \mathrm{d}$ and tended to increase milk fat content and yield of milk and protein (Broderick et al. 2009).

The utilization of condensed tannin as an additive in beef cattle diets with high level of concentrate and soybean meal as a source of true protein implies positive effects on crude protein utilization, decreasing digestion rate and ruminal digestibility of crude protein and consequently increasing the levels of metabolizable protein, with no changes in the ruminal fermentation parameters (Mezzomo et al. 2011). Meanwhile, balancing rumen degradable peptide supply to predicted requirement of ruminal microflora in steers improved fermentation efficiency and microbial output, which in turn improved animal performance (Brooks et al. 2012).

\section{Products of livestock}

Meat, milk or works are the primary products of livestock with concomitant yield of hide, fertilizer, 
biogas, or young stocks (offspring). The efficiency of livestock production is affected by the nutritive quality of feed. Gain over feed cost may be more important to consider as an indicator of the economic advantage of keeping livestock. Feed is the major portion of livestock production costs; therefore, reducing feeding cost is prime interest to increase the benefit. The value of feed conversion ratio (FCR) may be used as an indicator to describe the efficiency of the feed utilization. A better quality of feed may produce higher quality livestock products in terms of nutritive value such as protein content of meat or total solid content of milk.

\section{ADVANCED FEEDING MANAGEMENT}

Farmers can play a role in each step of digestion and metabolism processes to improve the efficiency of feed nutrient utilization. The intervention of farmers to the digestion process is called as beyond usual feeding management because farmers can change the physiological process and manipulate the rumen ecosystem and along the digestive tract or even at the stage of metabolism in tissue level.

An example of the already well-known interventions of human to the rumen ecosystem is the one that reducing the protozoa population, which is known as defaunation; either partial or complete defaunation. The advantage of defaunation is indicated by the increased bacteria due to the reduced protozoa that acts as predator for bacteria. Increasing the number of bacteria will increase the fibrous feed digestion and therefore increase the availability of energy in the form of volatile fatty acids and energy yielding reaction through the proton-electron transport mechanisms. Saponins can be used as primary component of defaunator agent because saponins will disrupt the protozoa cell membrane and resulting in killing the protozoa. Defaunation may be carried out by selective removal of protozoa from the rumen microbial ecosystem by a cell membrane cholesterol-saponin interaction, which causes cell rupture, increases the nitrogen utilization of the ruminant, and may lead to an increase in growth, milk, or wool production. The growth-promoting effect was evident in the high roughage diet suggesting that the application of saponins or saponin-containing plant materials may be beneficial for the subsistence farmers (Wina et al. 2005). Microbial diversity in the rumen ecosystem enhances the resistance of the network of metabolic pathways present, as well as increasing the potential number of new pathway available (Edwards et al. 2008).

\section{Development of feed technology}

To support the feeding system beyond traditional feeding management, we needs the development of technology associated with the efforts to improve the nutritive value of feedstuffs, either before or after being fed to the animals (Table 1). Ensilage and fermentation of feedstuffs are mainly to improve the nutritive value of feedstuffs before being fed to the animals. Supplementation with ionophore antibiotics, secondary compounds of plants such as saponin, tannin and other bio-active substances, rumen modifier and essential nutrients is targeted to improve the nutrient utilization after the feeds are taken by the animals. Technology related to the modification of physiological processes of feed utilization should be developed and should be appropriate for the local specific condition.

Supplementation of polyether ionophores such as monensin, lasalocid, gramicidin, salinomysin and valinomysin may manipulate the efficiency of fermentation for a better utilization of nutrients. The ionophores act as modifier in the transport of ions across biological membrane. Ionophores are antimicrobial compounds that are commonly fed to ruminant animals to alter the microbial ecology of the intestinal microbial consortium, resulting in increased carbon and nitrogen retention by the animal and hence increasing production efficiency (Callaway et al. 2003).

The effects of monensin and lasalocid have been compared, and the additive response of malate in rations containing ionophores was evaluated using lambs (Gonzalez-Momita et al. 2009). The dietary treatments were: (1) Diet with 30 parts per million (ppm) lasalocid; (2) Diet with $30 \mathrm{ppm}$ lasalocid and $0.3 \%$ malate; (3) Diet with $30 \mathrm{ppm}$ monensin; and (4) Diet with $30 \mathrm{ppm}$ monensin and $0.3 \%$ malate. Lambs fed diets with monensin had a $10.9 \%$ lower dry matter (DM) intake than those fed lasalocid. Malate had no effect on DM intake. Lambs fed monensin had lower NDF intake (37.8\%) than those fed lasalocid. When malate was included in the diet, NDF intake was also reduced by about $25 \%$. However, no difference in NDF digestibilities was observed between ionophores or by the addition of malate. Nitrogen balance was greater for lambs fed lasalocid diets, which had a higher crude protein intake, than lambs fed diets with monensin. Lambs fed diets with monensin or malate consumed less NDF and needed less time compared to those fed lasalocid. Lambs on the lasalocid diets consumed more fiber, which might be attributed to a greater selection of fibrous components of the diet (Gonzalez-Momita et al. 2009).

Feeding readily available nutrients in the rumen may also modulate the rumen function by affecting the 
Table 1. Technology for advanced feeding management

\begin{tabular}{|c|c|c|c|}
\hline Technology & Suggested mechanism & Qualitative response & References \\
\hline Ensilage fermentation & $\begin{array}{l}\text { Preserved nutrients; early } \\
\text { degradation }\end{array}$ & $\begin{array}{l}\text { Better nutritive value; higher } \\
\text { Lactobaccilus concentration; lower } \mathrm{pH}\end{array}$ & Gao et al. (2008) \\
\hline $\begin{array}{l}\text { Supplements of } \\
\text { ionophores }\end{array}$ & $\begin{array}{l}\text { Transport across } \\
\text { membrane; modification of } \\
\text { microbial activity }\end{array}$ & $\begin{array}{l}\text { Increased nitrogen retention; increased } \\
\text { animal growth rate }\end{array}$ & $\begin{array}{l}\text { Callaway et al. (2003); } \\
\text { Gonzalez-Momita et al. } \\
\text { (2009) }\end{array}$ \\
\hline Solubles nutrients & $\begin{array}{l}\text { Early nutrient availability } \\
\text { for rumen microbial use }\end{array}$ & Improved microbial activity & Benchaar et al. (2008) \\
\hline Protection & $\begin{array}{l}\text { Reducing rate of } \\
\text { degradation; replacing site } \\
\text { of digestion }\end{array}$ & Increased feed efficiency & Biricik et al. (2006) \\
\hline Probiotics & Enzyme modification & Improved feed utilization & Wallace et al. (2008) \\
\hline Encapsulation & Replacing site of digestion & $\begin{array}{l}\text { Improved growth rate; essential fat } \\
\text { composition }\end{array}$ & $\begin{array}{l}\text { Or-Rashid et al. (2009); } \\
\text { Wina et al. (2005) }\end{array}$ \\
\hline $\begin{array}{l}\text { Supplements of } \\
\text { enzymes }\end{array}$ & Inducing early digestion & Better digestibility in the rumen & Wallace et al. (2008) \\
\hline Supplement of sugar & $\begin{array}{l}\text { Early energy supply for } \\
\text { microbial activity }\end{array}$ & Improved microbial enzyme activity & Firkins (2011) \\
\hline Chelation of minerals & $\begin{array}{l}\text { Membrane transfer; } \\
\text { immune response }\end{array}$ & Improved growth rate and production & $\begin{array}{l}\text { Overton \& Yasui (2014); } \\
\text { Spears (1996) }\end{array}$ \\
\hline De-oiled feedstuffs & $\begin{array}{l}\text { Reduce fat effect on } \\
\text { microbial activity }\end{array}$ & Improved feed nutritive value & $\begin{array}{c}\text { Sereewatthanawut et al. } \\
\text { (2008) }\end{array}$ \\
\hline
\end{tabular}

microbial synergism by which efficiency of nutrient utilization can be improved. The use of forage liquor rather than the entire forage material may also modify the energy utilization since forage liquor is to be digested much easier by microbial enzyme systems as compared to the whole forage particle. Benchaar et al. (2008) indicated that plant extracts containing of essential oils that have antimicrobial properties that make them potential alternatives to antibiotics to manipulate microbial activity in the rumen. Over the last few years, a number of studies have examined effects of essential oil and their active components, on rumen microbial fermentation (Benchaar et al. 2008).

Modifying the site of digestion for dietary protein may increase the availability of amino acids for animal tissue metabolism. Therefore a technique of protection of dietary protein from rumen degradation has been developed for the highly soluble protein feedstuffs, such as palm kernel cake and soy bean meal (Haryanto 2014). Similar technique can also be developed for essential fatty acids such as linoleic and linolenic acids. The unsaturated long chain fatty acids are important in affecting energy utilization in ruminants. Several seed oils are important sources of unsaturated fatty acids such as safflower oil and sunflower oil. Ruminal ammonia-N concentrations were not affected from the degradability characteristics of protein. Rumen $\mathrm{pH}$ and acetate: propionate were higher in diets containing slowly degradable starch than in diets rapidly degradable starch. Propionic acid was higher in diets containing rapidly degradable starch than in diets containing slowly degradable starch. The experiment failed to conclude that fermentation and utilization of nutrients in the rumen were affected by starch degradability more than protein degradability. Synchronizing starch and protein degradation in rumen had no effect on the intake and digestibility of nutrients in sheep (Biricik et al. 2006).

Supplementation of readily soluble nitrogen such as urea to the rumen ecosystem increases the concentration of ammonia $\left(\mathrm{NH}_{3}\right)$ which is required for the microbial protein synthesis. The use of urea in the diet, however, should be limited to a low level, i.e., less than $1 \%$ in the diet to prevent the occurrence of ammonia toxicity. Urea supplementation of feed for ruminants at doses up to $1 \%$ of complete feed DM is considered safe when be given to animals with a well adapted ruminal microbiota and fed diets rich in easily digestible carbohydrates. The substitution of protein by urea in well balanced feed for ruminants would not result in an increased environmental nitrogen load (EFSA 2012). The short chain fatty acids (SCFA) absorption also accelerates urea transport into the rumen, which via ammonium recycling, may remove protons from rumen to the blood. Ammonium absorption into the blood was also stimulated by luminal SCFA, indicating that the interacting transport processes for SCFA, urea, and ammonia represented evolutionary adaptations of ruminants to actively coordinate energy fermentation, protein assimilation, 
and $\mathrm{pH}$ regulation in the rumen (Aschenbach et al. 2011).

Probiotics, which were defined as directly-fed microorganisms may be supplemented into the diets to manipulate the rumen microbial population, and therefore affect the enzyme production. The use of probiotics to improve the fibrous feed material digestion may be carried out prior to giving the feeds to the animal or by mixing it to the diets. Rumen microbes collected from slaughter houses can be used as preparation materials to produce probiotics under special processing management. Recent research on feed additives of natural or biological origin indicated that beyond replacement of growth-promoting antimicrobial feed additives in ruminant livestock production, it has potential commercial roles (Wallace et al. 2008).

Encapsulation of essential nutrients such as long chain unsaturated fatty acids, high protein concentrates, minerals and antioxidants may be beneficial to increase the efficiency of feed utilization, either biologically or economically. Recent experiments indicate that supplementation of protected conjugated linoleic acid reduced heat production and therefore increase the efficiency of energy utilization. Protected conjugated linoleic acid also reduces milk fat synthesis and increase the concentration of unsaturated fatty acids in the milk fat. Therefore, feeding a rumen-protected supplement containing eicosapentaenoic acid and docosahexaenoic acid, could be used to bypass the rumen (Or-Rashid et al. 2009).

Induction of cellulose degrading enzymes by cellobiose supplement in the rumen has been successful in increasing the utilization of energy as indicated by improvement of the cellulose digestibility by which more volatile fatty acids could be produced from the microbial fermentation activities. Cellobiose is a unit of 2 glucose monomers that can be obtained from the degradation of cellulose especially those from early emerging sprouts. Current scientific evidence suggests there is significant potential to use plants to enhance animal health in general and that of ruminants in particular. Active areas of research for plant bioactives (particularly saponin and tannin containing plants) include reproductive efficiency, milk and meat quality improvement, foam production/bloat control and methane production. Nematode control was also a significant area of research and the evidence suggests a much broader range of phytochemicals may be effective (Rochfort et al. 2008).

Supplementation of sugar solution increased the microbial enzyme activity which is required for the initiation of the degradation of cellulose. It suggested that the use of sugarcane shoots liquor which is high in sugar content may be a good strategy to increase the fibrous feed digestion. Sweet grasses contain high concentration of sugar as well, and this variety of grass has the potential to be developed in the future. In addition, the forage liquor could be used for bioethanol production while the residual from fermentative process was used as feedstuff for ruminants. Montagne et al. (2003) mentioned that diet had an important influence on gut health, including effects on proliferation of pathogenic bacteria and it could provide either beneficial or harmful input. Dietary fiber was a dietary component that had a major influence in this regard. There was evidence that some components of dietary fiber may improve gut health or alternatively enhance gut perturbation and subsequent diarrhea in young animals (Montagne et al. 2003).

Minerals are required by ruminants for microbial chemical reactions and for normal physiological processes of the animal. The biological value of minerals is affected by their conformation and ionic form. In many instances, the organic minerals are more effective than the inorganic ones such as zinc, copper and manganese. Chelation of those minerals with amino acids is already commercially marketed. A mixture of minerals which is specifically enriched with the essential elements may be given as mineral licks or mixed into the ration formula. The addition of one or more organic trace minerals to cattle diets has increased growth, milk production, reproduction and/or immune response in some studies. Zinc methionine has been studied to the greatest extent of any of the chelated or metal complex products available. Based on apparent absorption or tissue and blood concentrations, little evidence was available to suggest that organic trace minerals were considerably better absorbed than inorganic forms (Spears 1996). Trace minerals such as $\mathrm{Zn}, \mathrm{Cu}, \mathrm{Mn}$ and $\mathrm{Se}$ are essential with classically defined roles as components of key antioxidant enzymes and proteins. Available evidence indicates that these trace minerals could modulate aspects of oxidative metabolism and immune function in dairy cattle, particularly during the transition period and early lactation (Overton \& Yasui 2014).

Ahola et al. (2004) have reported using crossbred, multiparous beef cows to evaluate the effects of $\mathrm{Cu}, \mathrm{Zn}$ and $\mathrm{Mn}$ supplementation and source on performance in grazing cattle in eastern Colorado over a 2-year period. The results were not conclusive since in Year 1, the weight of calf weaned per cow were greater in controls than in supplemented cows and was greater in inorganic than organic treatments; however, opposite condition was found in year 2, indicating that supplementation and source of trace minerals affected the performance of beef cows in grazing system (Ahola et al. 2004).

De-oiled crop byproducts such as rice bran which contains fat approximately $15 \%$ of dry matter can be carried out leaving behind a higher protein content 
residue that have a higher nutritive value for ruminants. De-oiled rice bran by hydrolysis in sub-critical water (SW) in the temperature range between 100 and $220^{\circ} \mathrm{C}$ for 0-30 minutes suggested that SW could effectively be used to hydrolyze de-oiled rice bran to produce useful protein and amino acids (Sereewatthanawut et al. 2008).

Beta hydroxybutyric acid (BHBA), one of ketone bodies resulted from long chain fatty acids oxidation, is important in the energy balancing such as for milk fat synthesis in ruminant. Poly-beta-hydroxybutyric acid (PHB) was produced from xylose and lactose using Pseudomonas cepacia. Approximately 50\% PHB (grams of PHB/grams of biomass total) was produced (Young et al. 1994).

Feed blocks may reduce the use of concentrate feeds, thus reduce feeding cost and increase farmer's income. In addition to their nutritional and economical benefit, the success of feed block technology depends on its adoption by smallholders. Therefore, the active participation of farmers in the evaluation and transfer of feed block technology targeting their specific conditions was highly recommended (Ben Salem \& Nefzaoui 2003).

\section{Suggestion and recommendation}

Based on the present feeding system of livestock, it is suggested that practical feeding management of ruminants should include the recent technology in order to increase the efficiency of feed utilization. Providing nutrients to support maximal production performance of livestock closed to the genetic potency may adopt the recently developed technologies as long as practicable and economically appropriate to the local condition.

It is recommended that further development of technology through research associated with modification of digestion, fermentation, absorption and metabolism of nutrients should be carried out to increase the efficiency of feed utilization which should be followed by improving the animal product quality and economic efficiency.

\section{CONCLUSION}

Conventional feeding system by allowing the animal to find their own nutrient requirements under the existing resource condition, such as in grazing land or under estate crop area, may be inadequate to satisfy the nutrient requirement due to the relatively low nutritive value of the available feedstuffs. Intervention of livestock raisers to increase the efficiency of feed utilization could be carried out by applying the currently available technologies to modify the physiological digestion, fermentation, absorption, and metabolism of nutrients. Ration formulation using pretreated feedstuffs before being fed to the animals opens the possibility to elevate the livestock productivity to the maximum potency. Application of appropriate technologies to the existing local farming condition should be developed in line with efforts to increase livestock production.

\section{REFERENCES}

Ahola JK, Baker DS, Burns PD, Mortimer RG, Enns RM, Whittier JC, Geary TW, Engle TE. 2004. Effect of copper, zinc and manganese supplementation and source on reproduction, mineral status and performance in grazing beef cattle over a two-year period. J Anim Sci. 82:2375-2383.

Aschenbach JR, Penner GB, Stumpff F, Gäbel G. 2011. Ruminant nutrition symposium: Role of fermentation acid absorption in the regulation of ruminal $\mathrm{pH}$. J Anim Sci. 89:1092-1107.

Belanche A, Doreau M, Edwards JE, Moorby JM, Pinloche E, Newbold CJ. 2012. Shifts in the rumen microbiota due to the type of carbohydrate and level of protein ingested by dairy cattle are associated with changes in rumen fermentation. J Nutr. 142:1684-1692.

Ben Salem H, Nefzaoui a. 2003. Feed blocks as alternative supplements for sheep and goats. Small Rumin Res. 49:275-288.

Benchaar C, Calsamiglia S, Chaves AV, Fraser GR, Colombatto D, McAllister TA, Beauchemin KA. 2008. A review of plant-derived essential oils in ruminant nutrition and production. Anim Feed Sci Technol. 145:209-228.

Biricik H, Turkmen II, Deniz G, Gulmez BH, Gencoglu H, Bozan B. 2006. Effects of synchronizing starch and protein degradation in rumen on fermentation, nutrient utilization and total tract digestibility in sheep. Ital J Anim Sci. 5:341-348.

Broderick GA, Stevenson MJ, Patton RA. 2009. Effect of dietary protein concentration and degradability on response to rumen-protected methionine in lactating dairy cows. J Dairy Sci. 92:2719-2728.

Brooks MA., Harvey RM, Johnson NF, Kerley MS. 2012. Rumen degradable protein supply affects microbial efficiency in continuous culture and growth in steers. J Anim Sci. 90:4985-4994.

Callaway T, Edrington T, Rychlik J. 2003. Ionophores: their use as ruminant growth promotants and impact on food safety. Curr Issues Intest Microbiol. 4:43-51.

Edwards JE, Huws SA, Kim EJ, Lee MRF, Kingston-Smith AH, Scollan ND. 2008. Advances in microbial ecosystem concepts and their consequences for ruminant agriculture. Anim. 2:653-660. 
EFSA. 2012. Scientific opinion on the safety and efficacy of urea for ruminants. EFSA J. 10:2624.

Firkins JL. 2011. Liquid feeds and sugars in diets for dairy cattle. In: Ruminant Nutrition Symposium. Florida, 12 February 2011. Florida (US): University of Florida. p. $62-80$.

Gao L, Yang H, Wang X, Huang Z, Ishii M, Igarashi Y, Cui Z. 2008. Rice straw fermentation using lactic acid bacteria. Bioresour Technol. 99:2742-2748.

Gonzalez-Momita ML, Kawas JR, García-Castillo R, Gonzalez-Morteo C, Aguirre-Ortega J, HernandezVidal G, Fimbres-Durazo H, Picón-Rubio FJ, Lu CD. 2009. Nutrient intake, digestibility, mastication and ruminal fermentation of pelibuey lambs fed finishing diets with ionophore (monensin or lasalocid) and sodium malate. Small Rumin Res. 83:1-6.

Haryanto B. 2014. Manipulating protein degradability in the rumen to support higher ruminant production. Wartazoa. 24:131-138.

Hegarty RS. 2012. Livestock nutrition-A perspective on future needs in a resource-challenged planet. Anim Prod Sci. 52:406-415.

Mezzomo R, Paulino PVR, Detmann E, Valadares Filho SC, Paulino MF, Monnerat JPIS, Duarte MS, Silva LHP, Moura LS. 2011. Influence of condensed tannin on intake, digestibility and efficiency of protein utilization in beef steers fed high concentrate diet. Livest Sci. 141:1-11.

Montagne L, Pluske J, Hampson D. 2003. A review of interactions between dietary fibre and the intestinal mucosa, and their consequences on digestive health in young non-ruminant animals. Anim Feed Sci Technol. 108:95-117.
Or-Rashid MM, Wright TC, McBride BW. 2009. Microbial fatty acid conversion within the rumen and the subsequent utilization of these fatty acids to improve the healthfulness of ruminant food products. Appl Microbiol Biotechnol. 84:1033-1043.

Overton TR, Yasui T. 2014. Practical applications of trace minerals for dairy cattle. J Anim Sci. 92:416-426.

Rochfort S, Parker AJ, Dunshea FR. 2008. Plant bioactives for ruminant health and productivity. Phytochemistry. 69:299-322.

Sereewatthanawut I, Prapintip S, Watchiraruji K, Goto M, Sasaki M, Shotipruk A. 2008. Extraction of protein and amino acids from deoiled rice bran by subcritical water hydrolysis. Bioresour Technol. 99:555-561.

Spears JW. 1996. Organic trace minerals in ruminant nutrition. Anim Feed Sci Technol. 58:151-163.

Wagner JJ, Engle TE, Bryant TC. 2010. The effect of rumen degradable and rumen undegradable intake protein on feedlot performance and carcass merit in heavy yearling steers. J Anim Sci. 88:1073-1081.

Wallace RJ, Colombatto D, Robinson PH. 2008. Enzymes, direct-fed microbials and plant extracts in ruminant nutrition. Anim Feed Sci Technol. 145:1-4.

Wina E, Muetzel S, Becker K. 2005. The impact of saponins or saponin-containing plant materials on ruminant production-A review. J Agric Food Chem. 53:80938105.

Young FK, Kastner JR, May SW. 1994. Microbial production of poly-beta-hydroxybutyric acid from d-xylose and lactose by Pseudomonas cepacia. Appl Environ Microbiol. 60:4195-4198. 